\title{
Ontogeny of pituitary gonadotrophin secretion in the fetal and post-natal pig in response to LHRH in vitro
}

\author{
F. Elsaesser, T. O. Bruhn* and N. Parvizi \\ Institut für Tierzucht und Tierverhalten (FAL), Mariensee, 3057 Neustadt 1, \\ Federal Republic of Germany
}

\begin{abstract}
Summary. Monolayer cultures of anterior pituitary cells from male or female pigs of $60,80,105$ days of fetal life or of 60,160 and 250 days of post-natal life were prepared and treated with LHRH ( 1 pM to $10 \mathrm{nM}$ ). Dose-related increases of LH were first seen at 80 days of gestation in both sexes, while only female fetuses responded to maximal LHRH at 60 days. Basal and stimulated LH release doubled in cultures from 105-dayold fetuses when compared with those at 80 days. Compared to late fetal stages $\mathrm{LH}$ release was 20 - to 30 -fold higher in cell cultures from 60 -day-old (post-natal) donors without further change during the post-natal period. In all pre- and post-natal age groups basal and maximal LH release of pituitary cells from males was lower than that of females.

FSH stimulation started in male and female cells at 80 days of gestation only at LHRH concentrations exceeding or equal to $0.1 \mathrm{nM}$. By 105 days FSH secretion was dose-related and pituitary cells of females responded with higher FSH values than did those of males. In general, post-natal cells released much higher amounts of FSH than did prenatal cells. Basal and maximal release of FSH decreased during post-natal development in both sexes. Basal as well as maximal FSH release of cultures from female donors was higher than that found in cultures from male donors.

Determination of total LH and FSH content in fetal pituitary cell cultures indicated that the developmental increase in gonadotrophin release potential is a function of the total gonadotrophin content in vitro.

We conclude that (1) the in-vitro release of gonadotrophins to LHRH is dose-, ageand sex-dependent; (2) in the female fetal pig LH responsiveness develops earlier than FSH responsiveness; (3) apparently, these maturational changes mainly reflect alterations in pituitary gonadotrophin content; and (4) there is no simple relationship between in-vitro release and circulating gonadotrophins.
\end{abstract}

Keywords: pig; pituitary; FSH; LH; secretion; fetal; post-natal; sexual development

\section{Introduction}

During pre- and post-natal development of the pig plasma gonadotrophin concentrations show characteristic changes. Elevations of fetal plasma gonadotrophins are prominent in the last third of gestation (Elsaesser et al., 1976; Colenbrander et al., 1977, 1982a). It has been postulated that changes of gonadotrophins in the fetal circulation are the result of a maturation of the fetal hypothalamus-pituitary axis. In-vivo studies involving stimulation of fetal gonadotrophin secretion with exogenous LHRH in the pig (Colenbrander et al., 1982b) suggest that the fetal pituitary may become more responsive to releasing factors during development. Results of electrical stimulation of the hypothalamus also indicate maturational changes (Bruhn et al., 1983).

\footnotetext{
*Present address: Division of Endocrinology, Rhode Island Hospital, Brown University, 593 Eddy Street, Providence, RI 02902, U.S.A.
} 
We have developed a monolayer culture system to study the control of gonadotrophin secretion during pre- and post-natal development and changes of basal and LHRH stimulated gonadotrophin secretion in vitro have been examined.

\section{Materials and Methods}

\section{Fetal experiments}

Animals. Pregnant gilts (German Landrace, $140-170 \mathrm{~kg}$ ) were kept under standard conditions in the Institute's facility. For the collection of fetal pituitaries, animals were killed on Day 60 (range 57-63), 80 (77-83) or 105 (101-109) of pregnancy (term: $114 \pm 2$ days). In each experiment 35-70 fetuses from 4-7 sows were used. After electrical stunning, the animals were exsanguinated and the uterus was immediately removed. Male and female fetuses were weighed and decapitated, and trunk blood was collected during exsanguination of the fetus. Skulls were opened with a band saw and pituitaries were removed (within 7-12 min after exsanguination of the sow) and placed into sterile cold $\left(4^{\circ} \mathrm{C}\right)$ Hepes buffer, in which anterior and posterior lobes were separated.

Media. Media were prepared according to Vale et al. (1972) and Miller et al. (1977). In brief, Hepes buffer, pH 7.6, consisted of $137 \mathrm{~mm}-\mathrm{NaCl}, 5 \mathrm{mM}-\mathrm{KCl}, 0.7 \mathrm{~mm}-\mathrm{Na}_{2} \mathrm{HPO}_{4} \cdot 2 \mathrm{H}_{2} \mathrm{O}, 25 \mathrm{~mm}-\mathrm{N}$-2-hydroxyethylpiperazine ethanesulphonic acid (Hepes), $10 \mathrm{~mm}$-glucose, $0 \cdot 1 \mathrm{~mm}-\mathrm{CaCl}_{2} \cdot 2 \mathrm{H}_{2} \mathrm{O}, 50 \mathrm{U}$ penicillin $\mathrm{G} / \mathrm{ml}$ (Hoechst, Frankfurt, W. Germany), $50 \mu \mathrm{g}$ streptomycin/ml (Sigma, St Louis, MO, U.S.A.) and $0 \cdot 1 \%$ amphotericin B (Seromed, München, W. Germany).

Dulbecco's modified Eagle's medium (DMEM), $\mathrm{pH} 7.5$ consisted of $10 \mathrm{~g}$ Instamed MEM Dulbecco (Seromed)/l, $10 \mathrm{~mm}$-Hepes (Serva, Heidelberg, W. Germany), $10 \mathrm{~mm}-\mathrm{NaHCO}_{3}, 1.0 \mathrm{~mm}$-sodium pyruvate (Serva), $2.0 \mathrm{~mm}$ glutamine, antibiotics and fungicides as described for Hepes buffer, and $1 \%$ non-essential amino acids (Seromed $\mathrm{K}$ 0293). DMEM was supplemented with $10 \%$ horse serum and $2.5 \%$ fetal calf serum (Difco, Detroit, MI, U.S.A.).

The collagenase solution contained $0 \cdot 3 \%$ collagenase ( $131 \mathrm{U} / \mathrm{mg}$, CLS II, Worthington, Freehold, NJ, U.S.A.), $3 \%$ bovine serum albumin (BSA, Fraction V) and $0.005 \%$ DNase (both from Sigma) in Hepes buffer.

The viocase solution contained $0.25 \%$ viocase (Gibco Europe, Glasgow, U.K.) and 3\% BSA in Hepes buffer.

Media and all other solutions were sterilized by ultrafiltration. Glassware used for the cell preparation was siliconized and autoclaved.

Cell dispersion and culture conditions. Cell dispersion was carried out according to Vale et al. (1972) separately for male and female fetuses. In brief, anterior pituitary tissue was washed in Hepes buffer and cut into 1-2 mm fragments. Fragments were centrifuged at $200 \mathrm{~g}$ for $10 \mathrm{~min}$, the supernatant discarded and the pellet weighed. Approximately $15 \mathrm{ml}$ collagenase solution/g tissue was added. After $15 \mathrm{~min}$ incubation in a shaking bath at $37^{\circ} \mathrm{C}$ the collagenase solution was removed and replaced. At 10 min intervals the tissue was gently triturated 10 times with a Pasteur pipette. When the cells appeared to be completely dispersed (after 20-50 min) the suspension was centrifuged for $10 \mathrm{~min}$ at $200 \mathrm{~g}$. The supernatants were discarded, the pellet(s) resuspended in viocase solution and incubated at $37^{\circ} \mathrm{C}$ for $10 \mathrm{~min}$ in a shaking bath. Cells were then filtered through a fine nylon mesh $(100 \mu \mathrm{m})$, centrifuged and reconstituted with DMEM;33-5 washes with DMEM followed. Cell counts were determined with a haemocytometer.

The cell concentration was adjusted to $4 \times 10^{5}$ cells/ml DMEM with serum and $2 \mathrm{ml}$ of the cell suspension were added to each $35 \mathrm{~mm}$ culture dish (Falcon, Becton-Dickinson, Heidelberg, W. Germany). The dishes were kept at $37^{\circ} \mathrm{C}$ in $95 \%$ air $-5 \% \mathrm{CO}_{2}$ and a water-saturated atmosphere.

After incubation for $65 \mathrm{~h}$ dishes were washed 3 times with DMEM without serum and experimental incubations were performed. Graded doses of LHRH (Hoechst OP.N. 021, Frankfurt, W. Germany) were added to the medium shortly before it was incubated with cells. After incubation for $4 \mathrm{~h}$ supernatants were removed and stored frozen $\left(-20^{\circ} \mathrm{C}\right)$ for radioimmunoassay (RIA). To measure intracellular gonadotrophin contents, cells remaining in culture wells after removal of media were handled as described by Huang \& Miller (1980).

\section{Post-natal experiments}

Animals were killed on Day 60 (range 58-62 days), 160 (155-165 days) or 250 (240-260 days, sexually mature) of life. In each experiment 12-14 sows and 12-14 boars were used. Pituitaries were taken within 5-10 min. Media, cell dispersion and culture conditions were as described for fetal pigs except that collagenase from Boehringer (Mannheim, W. Germany) and pancreatin (Gibco Europe, Glasgow, U.K.) were used instead of collagenase from Worthington and viocase, respectively. These changes were partly necessary due to lack of availability of the material used in the fetal study. The two different enzyme preparations are compatible as determined by dispersion yields and LHRH responsiveness of the same batch of pituitary cells.

Cell division during cell culture. At the end of each experiment, 4-8 culture dishes from control or treatment groups were fixed with $60 \%$ ethanol and stained with Giemsa (Merck 9204). The number of cells per dish was determined by counting 3 times 25 predetermined areas of each dish.

Hormone analyses. LH and FSH were determined by homologous double-antibody RIA. DMEM or DMEM with serum added did not cause non-specific interference in the RIA. LH was measured as described previously (Pomerantz et al., 1974; Ponzilius et al., 1986). The standard was LER-786-3. The sensitivity of the assay was $0.2 \mathrm{ng} \mathrm{LH} / \mathrm{ml}$ plasma; the interassay variance was $6.0 \%$, and the intra-assay variance was $3.5 \%$. Samples of one age group were analysed in duplicate in the same assay using $100 \mu \mathrm{l}$ plasma or various dilutions of culture medium. 
FSH was analysed as described by Bruhn et al. (1983). Purified pig FSH (biological activity, $60 \times$ NIH-pFSH-p-1) and a specific anti-pig FSH serum were purchased from UCB-Bioproducts, Braine-L'Allend, Belgium. The antiserum was diluted 1:600 000, and $100 \mu \mathrm{l}$ bound approximately $40 \%$ of the iodinated FSH in the absence of unlabelled hormone. The inter-assay and intra-assay variances were $11 \%$ and $5 \%$, respectively. Sensitivity was $0.2 \mathrm{ng} \mathrm{FSH} / \mathrm{ml}$ plasma. Cross-reactivity with purified pig LH and pig TSH was less than $1 \%$. Samples of one age group were measured in duplicate in the same assay using $50 \mu \mathrm{l}$ or $100 \mu \mathrm{l}$ plasma or various dilutions of the culture medium.

Statistical analyses. Age- and sex-related differences in plasma $\mathbf{L H}$ and FSH concentration were determined by twoway analysis of variance for unbalanced data. Age-related differences in basal and maximal gonadotrophin release were analysed by one-way analysis of variance for completely randomized samples followed by the method of fitting constants. Sex differences in gonadotrophin release at each age level were determined by Student's $t$ test (Snedecor, 1956). Dose-response curves were evaluated on The Salk Institute's VAX computer system using the program 'ALLFIT' (de Lean et al., 1978).

Data are expressed as means \pm s.e.m. Each experiment was repeated once or twice with essentially the same results.

\section{Results}

\section{Body weight and pituitary weight development}

Anterior pituitary weight (Table 1) increased during fetal development but, in relation to body weight, anterior pituitary weights decreased from $0.0043 \%$ at 60 days to $0.0026 \%$ at 105 days (mean of male and female fetuses).

Anterior pituitary weight in post-natal age groups amounted to $76 \mathrm{mg}(n=42), 188 \mathrm{mg}(n=64)$, $240 \mathrm{mg}(n=25)$ at 60,160 and 250 days of age, respectively (means of males and females), which resulted in a further decrease of the portion of the anterior pituitary in relation to the body weight (for example $0.00027 \%$ in 160-day-old animals, $70 \mathrm{~kg}$ body weight).

Table 1. Body weight, anterior pituitary weight and plasma LH and FSH concentrations of pigs during gestation

\begin{tabular}{|c|c|c|c|c|c|}
\hline \multirow{2}{*}{$\begin{array}{l}\text { Age of } \\
\text { gestation } \\
\text { (days) }\end{array}$} & \multirow{2}{*}{$\begin{array}{l}\text { Sex of } \\
\text { fetus }\end{array}$} & \multirow{2}{*}{$\begin{array}{l}\text { Body } \\
\text { weight } \\
\text { (g) }\end{array}$} & \multirow{2}{*}{$\begin{array}{l}\text { Wt of anterior } \\
\text { pituitary* } \\
\text { (mg) }\end{array}$} & \multicolumn{2}{|c|}{ Hormone conc. ( $\mu \mathrm{g} / 1$ plasma $)$} \\
\hline & & & & LH & FSH \\
\hline 60 & $0^{*}$ & $\begin{array}{c}115 \pm 9 \\
(27) \\
112 \pm 6 \\
(17)\end{array}$ & $\begin{array}{r}5 \cdot 2 \\
(27) \\
4 \cdot 7 \\
(17)\end{array}$ & $\begin{array}{c}0.35 \pm 0.06^{\mathrm{a}} \\
(27) \\
0.51 \frac{ \pm 0 \cdot 11^{\mathrm{a}}}{(17)}\end{array}$ & $\begin{array}{c}0.64 \pm 0.35^{\mathrm{a}} \\
(14) \\
0.66 \pm 0.47^{\mathrm{a}} \\
(8)\end{array}$ \\
\hline 80 & $0^{*}$ & $\begin{array}{c}430 \pm 19 \\
(12) \\
411 \pm 30 \\
(15)\end{array}$ & $\begin{array}{l}11 \cdot 2 \\
(26) \\
11 \cdot 5 \\
(27)\end{array}$ & $\begin{array}{c}0.34 \pm 0.05^{\mathrm{a}} \\
(36) \\
1 \cdot 02 \pm 0.08^{\mathrm{b}} \\
(37)\end{array}$ & $\begin{array}{c}0.51 \pm 0.25^{\mathrm{a}} \\
(29) \\
1.73 \pm 0.23^{\mathrm{b}} \\
(33)\end{array}$ \\
\hline 105 & 3 & $\begin{array}{c}1043 \pm 78 \\
(15) \\
1076 \pm 70 \\
(25)\end{array}$ & $\begin{array}{l}27 \cdot 6 \\
(25) \\
28 \cdot 0 \\
(15)\end{array}$ & $\begin{array}{c}1 \cdot 04 \pm 0 \cdot 10^{\mathrm{b}} \\
(35) \\
1 \cdot 37 \pm 0 \cdot 13^{\mathrm{c}} \\
(26)\end{array}$ & $\begin{array}{c}2.07 \pm 0.25^{\mathrm{b}} \\
(29) \\
4 \cdot 60 \pm 0.27^{\mathrm{c}} \\
\frac{(24)}{}\end{array}$ \\
\hline
\end{tabular}

Values are mean \pm s.e.m. for the no. of animals indicated in parentheses.

*Anterior pituitaries were pooled and weighed to allow quick preparation of the cells.

Different superscripts indicate significant differences between means $(P<0.05)$.

\section{Plasma LH and FSH concentrations during fetal life}

In the male circulating LH and FSH concentrations were low at 60 and 80 days of fetal life and thereafter increased $(P<0.05$; Table 1$)$. Concentrations in female fetuses rose as early as 80 days of 
gestation $(P<0.01)$; a further increase was evident at 105 days $(P<0.05)$. Female fetuses had higher plasma LH and FSH concentrations at 80 and 105 days than did male fetuses $(P<0.01)$.

\section{Cell dispersion and cell counts}

Cell yield, determined as number of anterior pituitary cells $/ \mathrm{mg}$ tissue, was $21.8 \times 10^{4}$ (range $11 \cdot 0-36.0)$ at 60 days, $16.2 \times 10^{4}(7.4-33.0)$ at 80 days and $16.8 \times 10^{4}(10.0-24.0)$ at 105 days. In post-natal pigs, anterior pituitary cells/mg tissue decreased from $10.4 \times 10^{4}$ (range 8.8-12.1) at 60 days to $4.9 \times 10^{4}(4.3-5.6)$ at 160 days and $2.5 \times 10^{4}(1.8-2.9)$ at 250 days of age. Viability, as determined by the trypan blue exclusion test, was more than $90 \%$ in each experiment. Immediately after and up to $12 \mathrm{~h}$ after plating the shape of the cells was spherical; after about $24 \mathrm{~h}$ in culture the cells were planar. At $40 \mathrm{~h}$ after plating, a monolayer culture had developed; overgrowing of fibroblasts, even after 5 days in culture, was not observed. Plating efficiency, as judged by the number of attached cells 3 days after plating, was more than $85 \%$ for fetal and post-natal age groups and was not affected by age or sex of the donor. After 5 days of culture, plating efficiency amounted to $118 \%$, indicating cell division during cell culture (data from 80- and 105-day-old fetuses).

\section{Effect of $L H R H$ on the release of $L H$ and FSH from fetal pituitaries}

Day 60 of gestation. Because of the limited amount of pituitary tissue available at this age, only two doses of LHRH could be used. Even $10 \mathrm{~nm}$-LHRH did not significantly stimulate LH release in cultures from male fetal cells. LH release was higher in LHRH-treated dishes from female fetuses compared to male fetuses $(P<0.01$, Fig. 1). There was no sex difference in the release of FSH and LHRH was ineffective in stimulating FSH secretion in either sex.

Day 80 of gestation. LHRH stimulated LH release in a dose-dependent manner (Fig. 1). LH release induced by LHRH was significantly increased at a concentration of $0.1 \mathrm{nM}(P<0.001$ compared to controls) in cells from males and females.

The minimum effective dose of LHRH necessary to induce FSH secretion from male pituitary cells was $1 \mathrm{~nm}$; the respective value for female cells was $10 \mathrm{nM}-\mathrm{LHRH}$. FSH release from female cells was apparently lower than that from male cells. The dose of LHRH necessary for a half maximal response $\left(\mathrm{ED}_{50}\right)$ was similar in both sexes, but higher for FSH than for $\mathrm{LH}$ (Fig. 1).

Day 105 of gestation. The sex difference observed at 60 and 80 days of fetal life was also evident at 105 days (Fig. 1). Basal and maximal LH secretion doubled between 80 and 105 days, but the ED $_{50}$ values were similar for both age groups.

FSH release from pituitary cells of females was significantly $(P<0.05)$ increased above basal levels by 0.05 nM-LHRH, whereas $1 \mathrm{nM}-\mathrm{LHRH}$ was the minimal effective dose to induce FSH release from pituitaries of males. The $\mathrm{ED}_{50}$ for $\mathrm{FSH}$ release of cells from female fetuses was lower than that from male fetuses (Fig. 1).

Basal and maximal FSH release from cells of male fetuses did not change between 80 and 105 days of age. The maximal amount of FSH released from pituitary cells of female fetuses at 105 days of age was about 2.5 times that observed at 80 days $(P<0.01$, see also Table 2$)$. The basal FSH release from pituitaries of females at 105 days of age was not greater than that at 80 days.

\section{Total gonadotrophin content of fetal pituitary cell cultures}

When intracellular LH and FSH contents were determined in prenatal age groups, contents of both gonadotrophins decreased as dose of LHRH increased. Total gonadotrophin content, calculated by adding the media levels and intracellular levels for each dose of LHRH were not affected by the dose of LHRH and increased $(P<0.01)$ for both gonadotrophins with fetal age (Table 2 ). During the 4-h incubation period with the maximal dose of LHRH (10 nM) LH release amounted to approximately $25 \%$ at 60 days and $50 \%$ of the total amount of LH stored in the pituitary cells at 


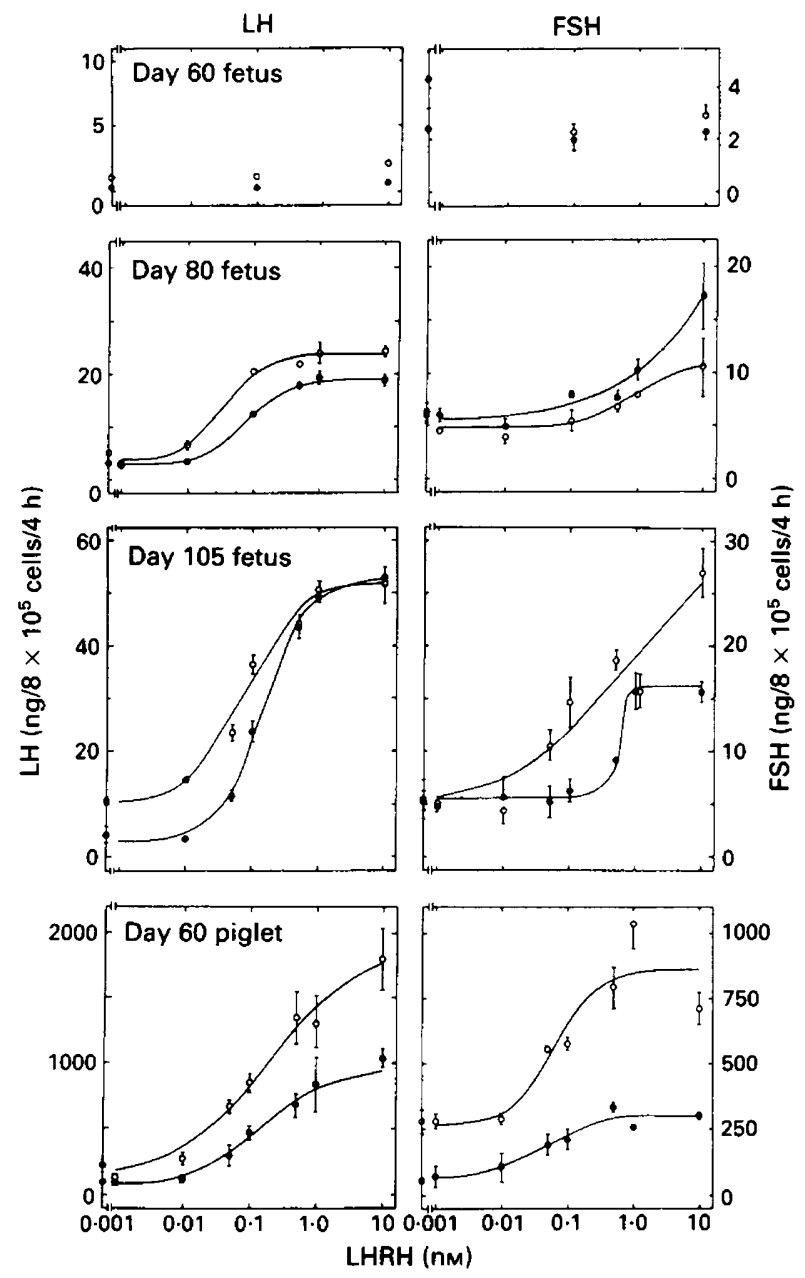

Fig. 1. Effect of different concentrations of LHRH on LH and FSH release by cultured anterior pituitary cells from male $(\bullet)$ and female $(O)$ pig fetuses at 60,80 and 105 days of age as well as 60 days after birth. Results are presented as means \pm s.e.m. obtained from 4 monolayer culture dishes. Designations of s.e.m. smaller than the symbols depicting the datum points are not shown.

80 or 105 days. The respective figures for FSH release were nearly $100 \%$ at 60 and 80 days and approximately $50 \%$ at 105 days of fetal age.

\section{Effect of $L H R H$ on the release of $L H$ and $F S H$ from post-natal pituitaries}

No developmental changes of LH response of post-natal anterior pituitary cells to LHRH were observed. Results are summarized in Table 2. A typical example of post-natal LHRH-induced dose-response curves of LH and FSH secretion (60 days) is shown in Fig. 1.

The sex difference observed in fetal cultures was also consistently present at all post-natal ages. Basal release as well as maximal LH release from female pituitary cells was approximately twice as high as that of male cells. The main difference between late fetal stages and post-natal ages was related to the amount of $\mathrm{LH}$ released per dish, which was 20 - to 30 -fold higher in post-natal pigs compared to cultures from 105-day-old fetuses $(P<0 \cdot 001)$. The minimum active dose of LHRH in 
F. Elsaesser et al.

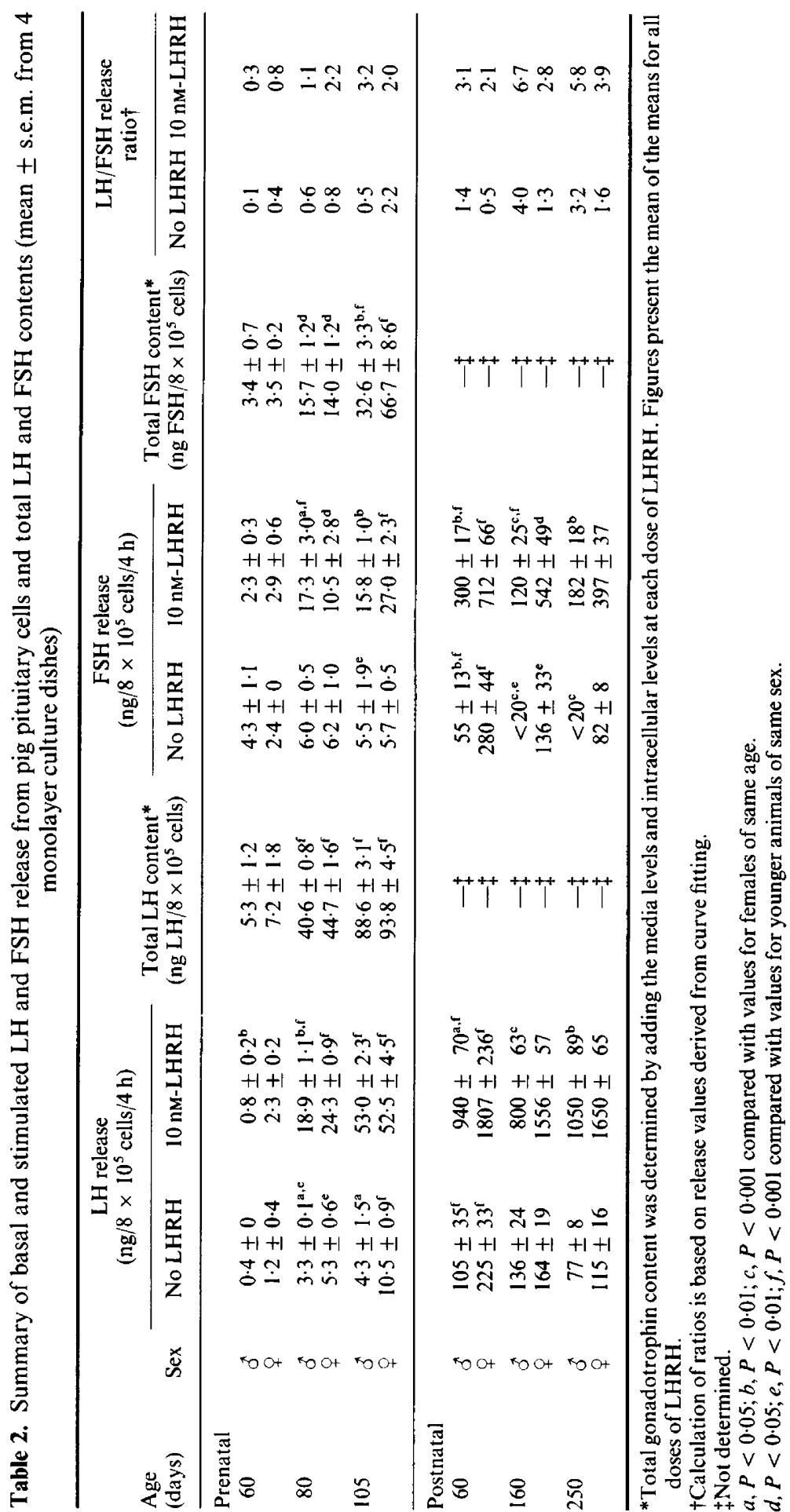


inducing $\mathrm{LH}$ secretion varied between 0.05 and $0.1 \mathrm{nM}$ with no apparent differences between age groups; $10 \mathrm{~nm}$-LHRH produced an approximately 10 -fold increase in $\mathrm{LH}$ release over basal $\mathrm{LH}$ release (Table 2). The $\mathrm{ED}_{50}$ values were similar for both sexes and all age groups.

For all age groups basal as well as maximal FSH release from female cells was significantly higher $(P<0.01)$ than that from male cells (Table 2). In general, the minimum effective doses of LHRH $(0 \cdot 05-0 \cdot 1 \mathrm{nM})$ were similar for FSH and LH. Basal and maximal release of FSH decreased between 60 days and 160 days in both sexes $(P<0.05)$. The ratio of basal to maximal release of FSH was rather constant for all ages and both sexes and varied between $3 \cdot 1$ and $7 \cdot 5$. The ability of post-natal anterior pituitary cells to release FSH was much higher than that of prenatal cells as was the case for LH. The dose of LHRH necessary for a half-maximal response of FSH varied considerably with age and sex without any apparent trend.

\section{Ratio of $L H: F S H$ release}

Changes in the release ratios of LH:FSH (Table 2) deserve attention, as they might be of developmental significance. In both sexes a shift of the relative gonadotrophin dominance towards $\mathrm{LH}$ was observed. Before birth the LH:FSH ratio (basal release) was $<1$ with a tendency to increase, whereas post-natally this ratio generally increased to $>1$. A similar age-dependent increase for the LH:FSH ratio derived from gonadotrophin release data in the presence of $10 \mathrm{nM}-\mathrm{LHRH}$ was observed, indicating that $\mathrm{LH}$ secretion in response to LHRH is rising faster with fetal age than the FSH release, respectively, the response of FSH to LHRH decreases post-natally.

\section{Discussion}

Typical LHRH dose-response curves (post-natal pituitaries) were S-shaped; half-maximal release of LH occurred at $0.035-0.36 \mathrm{~nm}-\mathrm{LHRH}$ which is in the order of magnitude found by others with pig pituitaries (Walker \& Hopkins, 1978). It is likely that the $10 \mathrm{nM}$-LHRH dose used in the present study reached the maximal effective dose, because no or only a small further increase in LH release was found with LHRH concentrations exceeding $10 \mathrm{nM}$ (Nakano et al., 1976; Walker \& Hopkins, 1978). In the present investigation $10 \mathrm{nM}-\mathrm{LHRH}$ provoked an approximately 10-fold increase in LH release from cells of animals older than 105 days of gestation which is very similar to the observation of Walker \& Hopkins (1978) who used pig pituitary cells derived from adult donors.

A consistent finding in all age groups studied was the sex difference in basal and stimulated LH secretion. With the exception of 80-day-old fetuses, FSH secretion was also higher in cultures from females compared to males. Our study indicates that the sex difference in FSH secretion at 105 days of fetal life reflects dissimilarities in the total content of FSH in culture. Furthermore, during the late fetal period and the first weeks after birth female pig pituitaries contain comparatively higher amounts of FSH but not LH than male pituitaries (Hennen et al., 1982). A sex-specific difference in the LHRH-induced LH or FSH release or both was also observed in vivo in the fetuses of cows (Kiser et al., 1975), sheep (Mueller et al., 1981) and pigs (Colenbrander et al., 1982b).

Sklar et al. (1981) and Mueller et al. (1981) have postulated that androgens, concentrations of which in the fetal circulation are higher in the male than in the female sheep, might be responsible for this sex difference in gonadotrophin secretion. This possibility gets experimental support from in-vitro studies in the rat, indicating that testosterone may be one of the factors contributing to the sex difference in the pituitary LH response to LHRH (Naor et al., 1978; Tang, 1978). Indeed, testosterone concentrations of male pigs exceed those of females even before birth (Ford et al., 1980). Testicular negative feedback regulation of LH secretion, however, does not appear to be operative in the pig during late fetal life and the first weeks of post-natal life (Ford \& Schanbacher, 1977; Colenbrander et al., 1977; Elsaesser et al., 1978; Ponzilius et al., 1986).

The physiological relevance of this prominent sex difference remains unclear. It has been suggested that the greater response of female pituitaries does provide sufficient LH for the 
pre-ovulatory LH surge at oestrus, whereas the lower response to LHRH in the male may meet the requirements for tonic LH secretion (Tang, 1978).

The present studies in vitro as well as those in vivo (Colenbrander et al., 1982b) suggest an agedependent development of $\mathbf{L H}$ release. It appears that this ontogenetic pattern of pituitary $\mathbf{L H}$ release is not only due to an age-dependent increase in pituitary cell number, since in our in-vitro system the number of adenohypophysial cells was kept constant. The mechanism responsible for the increase in LH responsiveness may be two-fold. First, it is possible that the ontogeny of LH secretion is due to changes in the number of LHRH receptors or to maturational changes of postreceptor events. Changes of the number of LHRH binding sites have been observed during sexual maturation of the rat (Chan et al., 1981), although it is not known whether these changes reflect changes in the number of LHRH receptors per LHRH-responsive cell alone or also changes in the number of LH/FSH secreting cells. Secondly, the percentage of LH/FSH cells per total number of anterior pituitary cells and pituitary gonadotrophin content may be increasing. In a preliminary immunohistochemical study (collaboration with Dr B. Colenbrander and Dr J. Meijer, Utrecht) we found an elevation in the percentage of $\mathrm{LH}$-producing cells in cultures of older fetuses compared to cultures of younger fetuses. In accordance with this finding, LH first appears in the pituitary of fetal pigs between Days 40 and 45; then the proportion of cells synthesizing LH (and FSH) increases progressively in number and staining intensity until Day 100 (Danchin \& Dubois, 1982; Dacheux \& Martinat, 1983; Meijer et al., 1985). One has to keep in mind, however, that LH/FSH secreting cells may contain too little gonadotrophin to be identified immunocytochemically in their earliest stages. The prenatal changes in LHRH responsiveness also correlate well with the total gonadotrophin content of fetal pituitary cell cultures in this study and with the developmental changes in pituitary content of $\mathrm{LH}$ in vivo (Hennen et al., 1982).

The pattern of FSH release from fetal pituitaries in vitro was similar to that described for $\mathrm{LH}$, but some differences should be emphasized. The half maximal effective doses of LHRH, considered as an indicator of pituitary sensitivity, were higher for FSH in comparison to those of LH. The ratio of maximal to basal release of FSH was lower than that for $\mathrm{LH}$, which agrees with previous observations made with rat anterior pituitary cells (Vale et al., 1972; Nakano et al., 1976). One other difference between LH and FSH secretion is related to the minimal effective dose of LHRH, which was higher for FSH than for LH. This difference is particularly evident in cells from 80-dayold fetuses and may indicate a delayed maturation of FSH secretion compared with LH secretion or differing control mechanisms or both. Dacheux \& Martinat (1983) also found that FSH appears later in the pituitary cells than does LH and that the number of LH-positive cells between Days 40 and 95 of fetal life is higher than the number of FSH-reactive cells. These findings could offer an explanation why electrical stimulation of the fetal hypothalamus can induce pituitary release of $\mathrm{LH}$ but not FSH (Bruhn et al., 1983).

Apart from sex differences, no changes in the characteristics of pituitary LH secretion throughout post-natal development were found, suggesting that gonadotrophs have reached their final secretory potential for $\mathrm{LH}$ release before puberty (about 200 days of age). Although we have not analysed total gonadotrophin content in cultures of post-natal pituitaries, the striking change between late fetal and prepubertal stages (60 days after birth), consisting of a 20 - to 30 -fold increase in basal and maximal LH release, certainly must reflect a substantial augmentation in pituitary $\mathrm{LH}$ content, as observed in vitro during the prenatal stages. In agreement with this assumption, Hennen et al. (1982) observed in vivo a prominent increase in pituitary LH content at 40 days after birth. Unlike the prenatal situation, this tremendous augmentation in secretory potential is not paralleled by comparable increases in circulating levels of LH (Elsaesser, 1982). It is possible that the postnatal augmentation in LH and FSH release potential per pituitary cell compensates for the substantial decrease in the portion of the anterior pituitary in relation to body weight and therefore blood volume.

In agreement with previous in-vivo studies (Guthrie et al., 1984) the dose-dependent response of pituitary FSH secretion to LHRH stimulation decreased with age after birth. In the gilt numerous 
small vesicular follicles develop between 60 and 120 days of post-natal life (Guthrie et al., 1984), which are known to contain high concentrations of inhibin (Channing et al., 1982; van de Wiel et al., 1983). Because inhibin selectively suppresses FSH synthesis and content of the anterior pituitary (Chowdhury et al., 1978; Scott \& Burger, 1981) it is possible that an age-dependent diminution in FSH responsiveness in vitro could reflect previous exposure of anterior pituitary cells to inhibin in vivo.

In conclusion, our results indicate that the in-vitro response of gonadotrophins to LHRH is dose-, age- and sex-dependent and that in the fetal pig LH response to LHRH develops earlier than FSH response to LHRH. These maturational changes appear to reflect alterations in numbers of gonadotrophs and/or pituitary gonadotrophin content. Evaluation of several publications on the ontogeny of basal plasma LH and FSH concentrations in male (Colenbrander et al., 1977, 1982a; Allrich et al., 1982) and female (for review see Christenson et al., 1985) pigs suggests that there is no simple relationship between in-vitro release and in-vivo concentrations of gonadotrophins and that postnatal maturational changes in the hypothalamo-pituitary axis, such as the development of the positive oestrogen feedback on LH release in the gilt (see Foxcroft et al., 1984), mainly involve maturation of control mechanisms other than pituitary responsiveness to LHRH.

This work was supported by the Deutsche Forschungsgemeinschaft Grant E1 44/13 and E1 46/6. We thank K. Brandes, U. Beermann, K. Klingemann, S. Schulze, A. Schulte-Derne and E. Hildewerth for excellent technical assistance.

\section{References}

Allrich, R.D., Christenson, R.K., Ford, J.J. \& Zimmerman, D.R. (1982) Pubertal development of the boar: testosterone, estradiol-17 $\beta$, cortisol and LH concentrations before and after castration at various ages. $J$. Anim. Sci. 55, 1139-1146.

Bruhn, T., Parvizi, N. \& Ellendorff, F. (1983) Ontogeny of hypothalamus-pituitary function in the fetal pig: gonadotropin release in response to electrical and electrochemical stimulation of the hypothalamus. Endocrinology 112, 639-644.

Chan, V., Clayton, R.N., Knox, G. \& Catt, K.J. (1981) Ontogeny of pituitary $\mathrm{GnRH}$ receptors in the rat. Endocrinology 108, 2086-2092.

Channing, C.P., Anderson, L.D., Hoover, D.J., Kolena, J., Osteen, K.G., Pomerantz, S.H. \& Tanabe, K. (1982) The role of non-steroidal regulators in control of oocyte and follicular maturation. Recent Progr. Horm. Res. 38, 331-408.

Chowdhury, M., Steinberger, A. \& Steinberger, E. (1978) Inhibition of de novo synthesis of FSH by Sertoli Cell Factor (SCF). Endocrinology 103, 644-647.

Christenson, R.K., Ford, J.J. \& Redmer, D. A. (1985) Maturation of ovarian follicles in the prepubertal gilt. J. Reprod. Fert., Suppl. 33, 21-36.

Colenbrander, B., Kruip, T.A.M., Dieleman, S.J. \& Wensing, C.J.G. (1977) Changes in serum LH concentrations during normal and abnormal sexual development in the pig. Biol. Reprod. 17, 506-513.

Colenbrander, B., van de Wiel, D.F.M., van Rossum-Kok, C.M.J.E. \& Wensing, C.J.G. (1982a) Changes in serum FSH concentrations in the pig during development. Biol. Reprod. 26, 105-109.

Colenbrander, B., Macdonald, A.A., Elsaesser, F., Parvizi, N. \& van de Wiel, D.F.M. (1982b) Response of lutein- izing hormone and follicle-stimulating hormone to luteinizing hormone releasing hormone in the fetal pig. Biol. Reprod. 27, 556-561.

Dacheux, F. \& Martinat, N. (1983) Immunocytochemical localization of LH, FSH and TSH in the fetal porcine pituitary. Cell Tiss. Res. 228, 277-295.

Danchin, E. \& Dubois, M.P. (1982) Immunocytological study of the chronology of pituitary cytogenesis in the domestic pig (Sus scrofa) with special reference to the functioning of the hypothalamo-pituitary-gonadal axis. Reprod., Nutr., Develop. 22, 135-151.

de Lean, A., Munson, P.J.C. \& Rodbard, D. (1978) Simultaneous analysis of families of sigmoidal curves: application to bioassay, radio-ligand assay, and physiological dose-response curves. Am. J. Physiol. 235, E97-E102.

Elsaesser, F. (1982) Endocrine control of sexual maturation in the female pig and sexual differentiation of the stimulatory oestrogen feedback mechanisms. In Control of Pig Reproduction, pp. 93-116. Eds D. J. A. Cole \& G. R. Foxcroft. Butterworths, London.

Elsaesser, F., Ellendorfi, F., Pomerantz, D.K., Parvizi, N. \& Smidt, D. (1976) Plasma levels of luteinizing hormone, progesterone, testosterone and $5 \alpha$ dihydrotestosterone in male and female pigs during sexual maturation. J. Endocr. 68, 347-348.

Elsaesser, F., Parvizi, N. \& Ellendorff, F. (1978) Steroid feed-back on luteinizing hormone secretion during sexual maturation in the pig. J. Endocr. 78, 329-342.

Ford, J.J. \& Schanbacher, B.D. (1977) Luteinizing hormone secretion and female lordosis behavior in male pigs. Endocrinology 100, 1033-1038.

Ford, J.J., Christenson, R.K. \& Maurer, R.R. (1980) Serum testosterone concentrations in embryonic and 
fetal pigs during sexual differentiation. Biol. Reprod. 23, 583-587.

Foxcroft, G.R., Elsaesser, F., Stickney, K., Haynes, N.B. \& Back, H.L. (1984) Ovarian oestrogen-dependent maturation of the $\mathrm{LH} / \mathrm{FSH}$ surge mechanism during prepubertal development in the gilt. $J$. Endocr. 101, 371-380.

Guthrie, H.D., Pursel, V.G., Bolt, D.J. \& Nachman, R.J. (1984) Effect of gonadotropin-releasing hormone, stage of sexual maturation and 6-methoxybenzoxazolinone on plasma gonadotropins, ovarian development and uterine weight in prepubertal gilts. Theriogenology 22, 683-692.

Hennen, G., McNamara, M., Vandalem, J.-L., Closset, J., Petit, R., Brooze, A., Colenbrander, B., Macdonald, A., van de Wiel, D. \& Meijer, J. (1982) Ontogenesis of gonadotropin receptors ( $\mathrm{LH}$ and FSH) during the neonatal period. Les Colloques I'INSERM 109, $481-502$.

Huang, E.S.-R. \& Miller, W.L. (1980) Effects of estradiol$17 \beta$ on basal and luteinizing hormone releasing hormone-induced secretion of luteinizing hormone and follicle stimulating hormone by ovine pituitary cell culture. Biol. Reprod. 23, 124-134.

Kiser, T.E., Convey, E.M., Lin, Y.C. \& Oxender, W.D. (1975) Luteinizing hormone and androgens in the bovine fetus after gonadotropin-releasing hormone. Proc. Soc. exp. Biol. Med. 149, 785-789.

Meijer, J.C., Colenbrander, B., Poot, P. \& Wensing, C.J.G. (1985) Development of pituitary gonadotrophic cells in the pig fetus and the effect of luteinizing hormone-releasing hormone administration. Biol. Reprod. 32, 137-143.

Miller, W.L., Knight, M.M., Grimek, H.J. \& Gorski, J. (1977) Estrogen regulation of follicle stimulating hormone in cell cultures of sheep pituitaries. Endocrinology 100, 1306-1316.

Mueller, P.L., Sklar, C.A., Gluckman, P.D., Kaplan, S.L. \& Grumbach, M.M. (1981) Hormone ontogeny in the ovine fetus. IX. Luteinizing hormone and folliclestimulating hormone response to luteinizing hormone-releasing factor in mid-and late gestation in the neonate. Endocrinology 108, 881-886.

Nakano, H., Fawcett, C. P. \& McCann, S.M. (1976) Enzymatic dissociation and short-term culture of isolated rat anterior pituitary cells for studies on the control of hormone secretion. Endocrinology 98, 278-288.
Naor, Z., Zor, U., Meidan, R. \& Koch, Y. (1978) Sex difference in pituitary cyclic AMP response to gonadotropin-releasing hormone. Am.J. Physiol. 235, E37-E41.

Pomerantz, D.K., Ellendorf, F., Elsaesser, F., König, A. \& Smidt D. (1974) Plasma LH changes in intact adult, castrated adult and pubertal male pigs following various doses of synthetic luteinizing hormone-releasing hormone (LH-RH). Endocrinology 94, 330-335.

Ponzilius, K.-H., Parvizi, N., Elsaesser, F. \& Ellendorff, F. (1986) Ontogeny of secretory patterns of LH release and effects of gonadectomy in the chronically catheterized pig fetus and neonate. Biol. Reprod. 34, $602-612$.

Scott, R.S. \& Burger, H.G. (1981) Mechanism of action of inhibin. Biol. Reprod. 24, 541-550.

Sklar, C.A., Mueller, P.L., Gluckman, P.D., Kaplan, S.L., Rudolph, A.M. \& Grumbach, M.M. (1981) Hormone ontogeny in the ovine foetus. VII. Circulating luteinizing hormone and follicle-stimulating hormone in midand late gestation. Endocrinology 108, 874-880.

Snedecor, G.W. (1956) Statistical Methods: Section M, p. 291. Iowa State University Press, Ames.

Tang, L.K.L. (1978) Sex difference in LH response to LHRH and DBcAMP and effect of testosterone. Am. J. Physiol. 235, E291-E294.

Vale, W., Grant, G., Amoss, M., Blackwell, R. \& Guillemin, R. (1972) Culture of enzymatically dispersed anterior pituitary cells: functional validation of a method. Endocrinology 91, 562-572.

van de Wiel, D.F.M., Bar-Mir, S., Tsafriri, A. \& de Jong, F.H. (1983) Oocyte maturation inhibitor, inhibin and steroid concentrations in porcine follicular fluid at various stages of the oestrous cycle. J. Reprod. Fert. 68, 247-252.

Walker, A.M. \& Hopkins, C.R. (1978) Stimulation of luteinizing hormone release by luteinizing hormonereleasing hormone in the porcine anterior pituitary: the role of cyclic AMP. Molec. cell. Endocr. 10, 327-341. 